\title{
A short and efficient construction of the dibenzo[c,h]chromen-6-one skeleton
}

\author{
Murat K. Deliömeroğlu, ${ }^{a}$ Sevil Özcan, ${ }^{\text {a,b }}$ and Metin Balci ${ }^{\text {* }}$ \\ ${ }^{a}$ Department of Chemistry, Middle East Technical University, 06531 Ankara, Turkey \\ ${ }^{\mathrm{b}}$ Department of Chemistry, Abant Izzet Baysal University, 14280 Bolu, Turkey \\ E-mail: mbalci@metu.edu.tr
}

\begin{abstract}
We hereby report a major revision of the synthetic methodology for construction of the dibenzochromenone skeleton. Homophthalic acid derivatives were reacted with thionylchloride/DMF in the presence of $\mathrm{NaN}_{3}$. As the main product, dibenzochromenone derivatives were obtained. When the reaction was performed in the absence of $\mathrm{NaN}_{3}$, only isochromenones were formed. The mechanism of the formation of these products is discussed.
\end{abstract}

Keywords: Homophthalic acid, acyl azide, isocoumarin, dibenzochromenone, arnottin I.

\section{Introduction}

Dibenzo[c, $h]$ chromen-6-one $\mathbf{1}$ motifs are of considerable interest due to their biological activity and structural intricacies. They exhibit a wide range of biological activities. ${ }^{1}$ 
<smiles>O=c1oc2c3ccccc3ccc2c2ccccc12</smiles>

1 Dibenzo[c,h]chromen-6-one<smiles></smiles>

3 defucogilvocarcin $M$<smiles></smiles>

2 arnottin I<smiles></smiles>

4 gilvocarcin $\mathrm{M}$

Arnottin I 2, a dibenzo[c, $h]$ chromen-6-one derivative was first isolated by Ishikawa and coworkers in 1977, as a minor constituent from the bark of Xanthoxylum arnottianum. ${ }^{2}$ However, the structure of this compound was not determined until 1993 since the producing plant yielded only small quantities of the material. ${ }^{3}$ Gilvocarcins $3,4,{ }^{4}$ a relatively small family of natural antibiotics having the dibenzo[c, $h]$ chromenone skeleton, also exhibit diverse biological activity. ${ }^{5}$ The key step in syntheses of these compounds has been mainly metal-catalyzed aryl-aryl coupling reactions of the suitable substituted starting materials which were synthesized by multistep procedures. James and Snieckus used mainly Negishi/Suzuki cross coupling followed by a remote metallation (DreM)-carbamoyl migration strategy. ${ }^{5}$ Ishikawa et al. used palladiumcatalyzed coupling of $o$-bromobenzoates and 1-tetralones to construct the dibenzo[c, $h]$ chromenone structure. ${ }^{6}$ Suzuki et al. used a three component system for the synthesis of defucogilvocarcin M 3. ${ }^{7}$ Nickel-catalyzed synthesis of benzocoumarin derivatives and its application to the total synthesis of arnottin I 2 was achieved by Madan and Cheng. ${ }^{8}$ In this paper, we describe a concise procedure leading directly to the core skeleton of dibenzo[c, $h]$ chromenone structure with some substituents resembling the arnottin I structure 2. Furthermore, the position of the substituents in the products should provide information about the mechanism of formation of the products.

\section{Results and Discussion}

Recently, we have treated homophthalic acid 5 with thionyl chloride, DMF, and sodium azide in the presence of tetrabutylammonium bromide as a catalyst. Unfortunately, the expected diazide 7 was not formed. The dibenzo[c, $h$ ]chromenone 1 was formed in $41 \%$ yield. ${ }^{9,10}$ In order to test the 
general applicability of this reaction for the formation of substituted dibenzo[c, $h]$ chromenones, substituted homophthalic acids were used. First, the original reaction was reinvestigated.

$\mathrm{N}, \mathrm{N}$-Dimethyl(chlorosulfinyloxy)methaniminium chloride formed from thionyl chloride and dimethyl formamide is an efficient reagent for the synthesis of acyl azides from carboxylic acids. ${ }^{10}$ Therefore, homophthalic acid $\mathbf{5}$ was reacted with thionyl chloride, DMF, and sodium azide, in the presence of tetrabutylammonium bromide as a catalyst in methylene chloride, anticipating formation of the diazide 7. However, the desired diazide 7 was not formed. Besides the major product, $6 H$-dibenzo $[c, h]$ chromen-6-one 1, an thioisocoumarin derivative $\mathbf{6}$ was isolated in $4 \%$ yield (Scheme 1). ${ }^{11,12}$

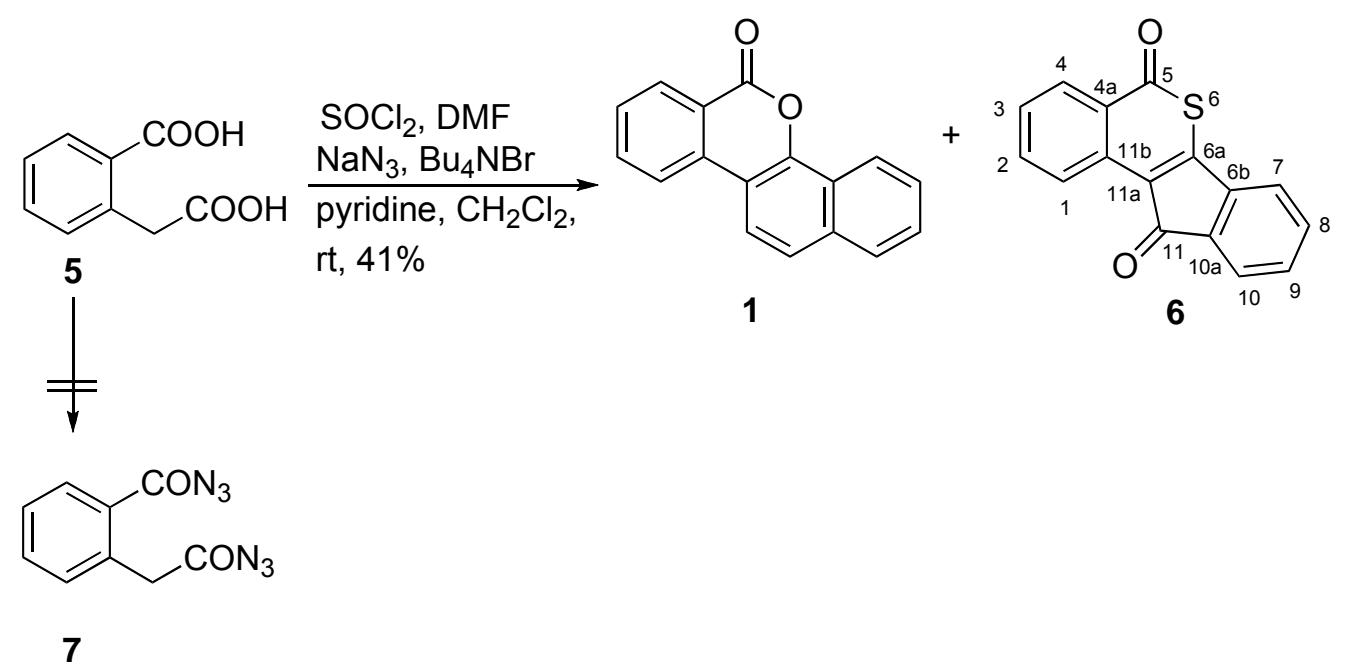

\section{Scheme 1}

COSY, HMQC, and HMBC experiments were conducted to confirm the the assignment of the structure of 6. Two carbonyl carbons appeared at 191.3 and $183.1 \mathrm{ppm}$, the high field resonance being that for the five-membered ring carbonyl carbon. With the help a of COSYspectrum we were able to distinguish between the aromatic protons of two benzene rings. The HMBC specrum showed that the carbonyl carbon resonance at 183.1 (C-5) correlates with the doublet (H-4) resonating at $8.17 \mathrm{ppm}$. On the other hand, the carbonyl carbon resonance at 191.3 (C-11) correlated with the doublet at $7.5 \mathrm{ppm}(\mathrm{H}-10)$. These observations clearly show that the carbonyl groups are directly connected to different benzene rings. The quaternary carbon atom C-6a correlated with the doublet resonating at 7.17 (H-7) whereas the carbon atom C-11a correlated with the doublet at $8.95 \mathrm{ppm}(\mathrm{H}-1)$. Those findings support the proposed structure. The incorporation of a sulfur atom into the molecule was determined by elemental analysis as well as by its mass spectrum. With the isolation of this new isothiocoumarin derivative $\mathbf{6}$, the focus of the research was directed to the increase of its yield. 


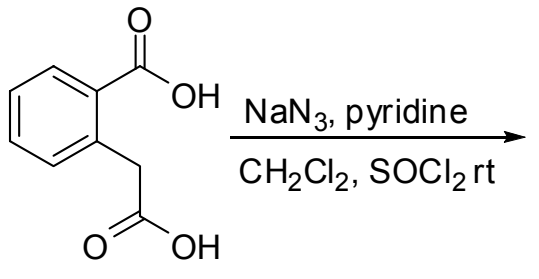

5
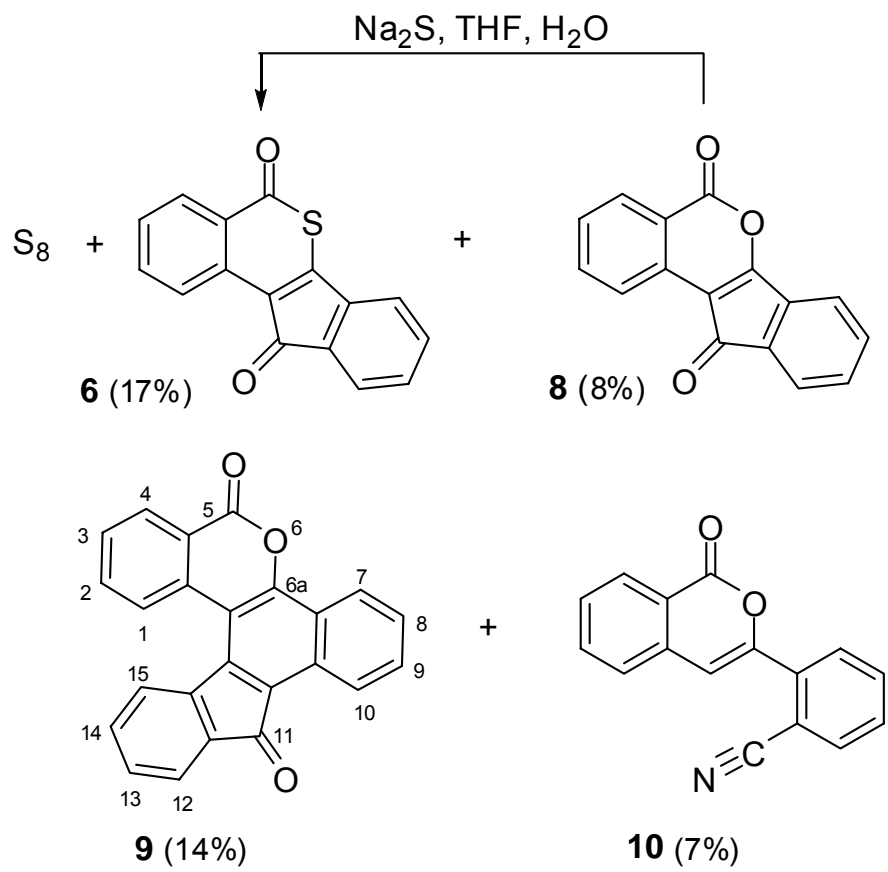

\section{Scheme 2}

The same reaction was carried out but in the absence of DMF. This procedure increased the yield of the isothiocoumarin derivative 6 from $4 \%$ to $17 \%$. On the other hand, elemental sulfur and new condensation products such as 8, 9 and $\mathbf{1 0}$ were isolated in 8, 14, and 7\% yields, respectively (Scheme 2). Interestingly, the major product $\mathbf{1}$, which was formed when the reaction was carried out in the presence of DMF, was not detected. This observation shows that DMF is involved in the formation of $6 H$-dibenzo[c,h]chromen-6-one $\mathbf{1}$. The spectral data of $\mathbf{8}$ was in agreement with those reported in the literature. ${ }^{13}$ The presence of three benzene rings in 9 was easily established by analysis of the ${ }^{1} \mathrm{H}$-NMR spectrum. The ${ }^{13} \mathrm{C}-\mathrm{NMR}$ spectrum had 22 lines for aromatic carbons. The carbonyl resonances observed at 191.8, $158.0 \mathrm{ppm}$ are in agreement with the proposed structures. COSY, HMQC, and HMBC spectra also support the structure. Again with the help of the COSY spectrum, the connection of the aromatic protons was easily determined. The HMBC spectrum showed correlation of the carbonyl resonance at 191.8 (C-11) ppm with the doublet resonating at 7.59 (H-12) ppm. The other carbonyl carbon at 160.4 (C-5) correlated with the doublet at $8.30(\mathrm{H}-4)$ ppm. Furthermore, the carbon atom at $151.2(\mathrm{C}-6 \mathrm{a})$ correlated with the doublet at 8.25 (H-7) ppm. Additionaly, the coupling constants between the protons $\mathrm{H}-7$ and H-8 $\left(J_{7,8}=8.4 \mathrm{~Hz}\right)$ and $\mathrm{H}-8$ and H-9 $\left(J_{8,9}=6.9 \mathrm{~Hz}\right)$ clearly showed the presence of a naphthalene unit in the proposed structure. The high resolution mass spectrum and the ${ }^{1} \mathrm{H}-$ NMR spectrum of $\mathbf{1 0}$ clearly indicated the presence of a nitrogen atom in the molecule. Nine proton resonances between 7.2-8.3 ppm, where one of them resonates as singlet, support the structure. Furthermore, an IR absorption band at $2225 \mathrm{~cm}^{-1}$ demonstrated the presence of a nitrile group. Two dimensional NMR spectra were also in agreement with the proposed structure $\mathbf{1 0 .}$ 
The sulfur containing product, indeno[1,2-c]isothiochromenone-5,11-dione $\mathbf{6}$ was synthesized independently, in quantitative yield, by reacting 8 with $\mathrm{Na}_{2} \mathrm{~S}$ in THF and water (1:1). Therefore, we assume that sulfide anion formed under the reaction conditions by reduction of $\mathrm{SOCl}_{2}$ by $\mathrm{NaN}_{3}$, ${ }^{14}$ substitutes oxygen atom in $\mathbf{8}$ to give $\mathbf{6}$. Sulfide anions formed under reaction conditions can undergo further reaction with excess $\mathrm{SOCl}_{2}$ present in the reaction media and produce elemental sulfur. In a separate reaction we successfully demonstrated that reaction of $\mathrm{Na}_{2} \mathrm{~S}$ with $\mathrm{SOCl}_{2}$ in dichloromethane produces sulfur in a very fast process.<smiles>O=C(O)Cc1ccccc1C(=O)O</smiles>

5

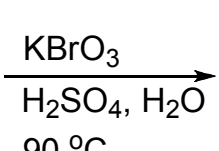
$90^{\circ} \mathrm{C}$<smiles>O=C(O)Cc1ccc(Br)cc1C(=O)O</smiles>

11

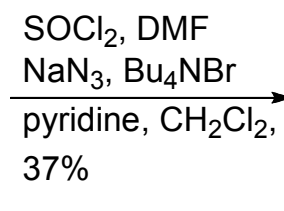

$\mathrm{SOCl}_{2}$, DMF

pyridine, $\mathrm{CH}_{2} \mathrm{Cl}_{2}$, $37 \%$<smiles>O=c1oc2c3cc(Br)ccc3ccc2c2ccc(Br)cc12</smiles>

$12(37 \%)$

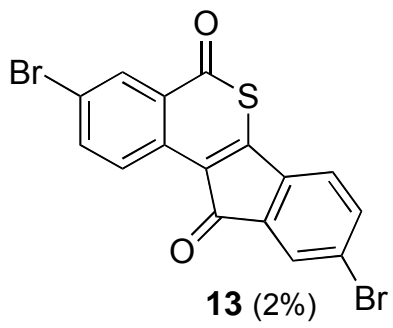

\section{Scheme 3}

In order to test the scope of the procedure shown in Scheme 1, the reaction was carried out with two substituted homophthalic acids. Bromohomophthalic acid $\mathbf{1 1}$ was synthesized by direct bromination of homophthalic acid. It is well known that the bromination of aromatic compounds containing electron-withdrawing groups has been an area of concern. Homophthalic acid $\mathbf{5}$ was reacted with potassium bromate ${ }^{15,16}$ in sulfuric acid to give the desired brominated diacid $\mathbf{1 1}$ in 44\% yield. Bromohomophthalic acid 11 was reacted with thionyl chloride, DMF and sodium azide, under the same reaction conditions as described in Scheme 1, to give dibromodibenzochromenone derivative $\mathbf{1 2}$ in $37 \%$ yield. The ${ }^{1} \mathrm{H}-\mathrm{NMR}$ spectrum was consistent with the proposed structure. In contrast to $\mathbf{1}$, this dibromo derivative $\mathbf{1 1}$ was found to be poorly soluble in organic solvents so that a ${ }^{13} \mathrm{C}-\mathrm{NMR}$ spectrum could not be recorded. Additionally, a minor compound $13(2 \%)$ was isolated. The structure was easily determined by comparison of the spectral data of $\mathbf{1 3}$ with those of $\mathbf{6}$. 
<smiles>COc1cccc(C(=O)O)c1</smiles>

14<smiles>COc1ccc2c(c1)C(=O)OC2C(F)(F)F</smiles>

15<smiles>COc1ccc(CC(=O)O)c(C(=O)O)c1</smiles>

$\mathrm{SOCl}_{2}, \mathrm{DMF}$ $\mathrm{NaN}_{3}, \mathrm{Bu}_{4} \mathrm{NBr}$ pyridine, $\mathrm{CH}_{2} \mathrm{Cl}_{2}$, rt, $45.3 \%$<smiles>COc1ccc2c(c1)c(=O)oc1c3cc(OC)ccc3ccc21</smiles>

17

\section{Scheme 4}

For the synthesis of 4-methoxyhomophthalic acid 16, a modified literature procedure was applied. ${ }^{17}$ Methoxybenzoic acid $\mathbf{1 4}$ was condensed with chloral hydrate to obtain the lactone $\mathbf{1 5}$, which was then reduced by zinc in acetic acid followed by hydrolysis to produce the methoxydiacid 16 (Scheme 4). With the synthesis of diacid 16, we were now able to assess its use for rapid and efficient generation of a dibenzochromenone skeleton, but with methoxyl substituents. Treatment of diacid 16 with thionyl chloride, DMF and sodium azide under the same reaction condition as reported for the synthesis of 12, resulted in the formation of the corresponding dimethoxydibenzochromenone derivative 17 in 45\% (Scheme 4). The structure and especially the exact positions of the methoxyl groups were determined with the help of COSY, HSQC and HMBC experiments.<smiles>COc1ccc(CC(=O)O)c(C(=O)O)c1</smiles>

16

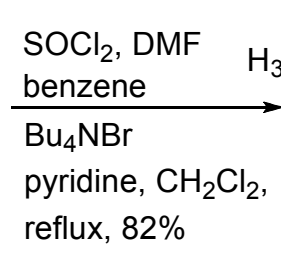

reflux, $82 \%$<smiles>COc1ccc2c(c1)C(=O)OC(=O)C2=CN(C)C</smiles><smiles>COC(=O)c1coc(=O)c2cc(OC)ccc12</smiles>

19

\section{Scheme 5}

During these reactions a nitrogen atom, arising from azide anion used in the reaction, was not incorporated in the products $\mathbf{1 2}, \mathbf{1 3}$ as well as $\mathbf{1 7}$. To determine the function of azide anion, the 
reaction with 16 was run in the absence of $\mathrm{NaN}_{3}$. Instead of the formation of a dibenzochromenone 17, an aminomethylene compound 18 was formed, which was converted to the isocoumarin derivative $\mathbf{1 9}^{18}$ by reaction with methanol saturated with hydrogen chloride (Scheme 5).

\section{Conclusions}

The reactions performed in our work show that the dibenzochromenone structure $\mathbf{1}$ can be easily generated, even with the substituted homophthalic acid derivatives, in $37-45 \%$ yields in a onepot reaction. Furthermore, the attempted azidination reactions of homophthalic acid derivatives 5, 11, and 16 show that $\mathrm{NaN}_{3}$ plays an important role in determination the mode of the reaction. In the absence of $\mathrm{NaN}_{3}$, isocoumarin derivative $\mathbf{1 9}$ was formed from the reaction of $\mathbf{1 6}$ instead of the dibenzocoumarin derivative 17. The mechanism we propose is shown in Scheme 6.

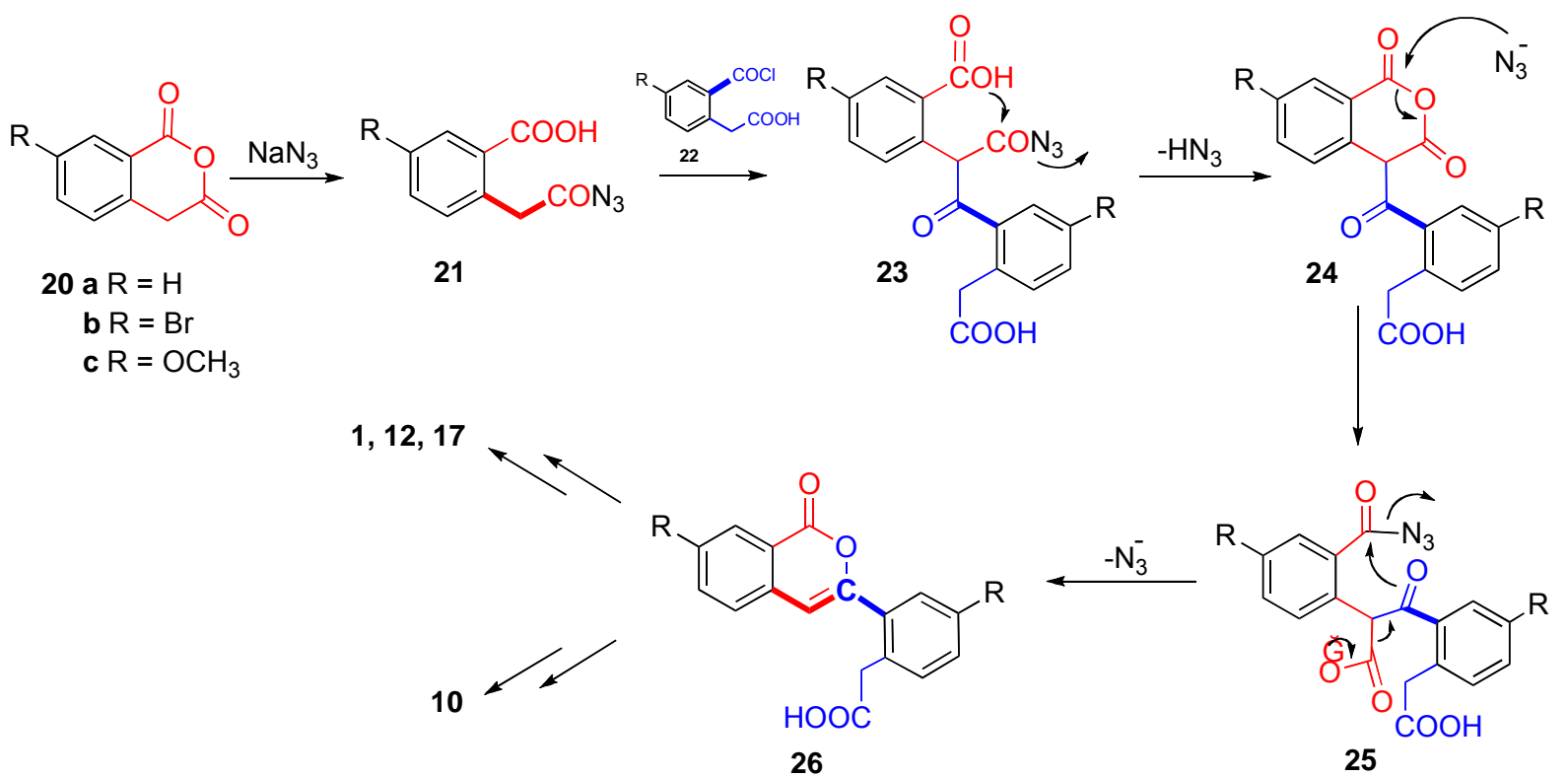

\section{Scheme 6}

We suggest that the first step is the formation of the anhydride $\mathbf{2 0}$, which could then be regiospecifically opened up by the azide anion to the corresponding monoazide 21. Formation of an acyl azide activates the methylenic protons for further reaction. Intermolecular acylation of 21 with acyl chloride $\mathbf{2 2}$ followed by ring-closure would result in the formation of $\mathbf{2 4}$. This anhydride might undergo again ring-opening by azide anion attack to form $\beta$-keto-acid carboxylate 25. Decarboxylation of $\mathbf{2 5}$ would lead to cyclization to form the key intermediate $\mathbf{2 6}$, which could easily be converted in the dibenzochromenone derivatives $\mathbf{1 , 1 2}$, and $\mathbf{1 7}$ as well as into the nitrile 10. Recently, Threadgill et al. ${ }^{19}$ obtained relevant information about the 
mechanism of the acylation of isocoumarin derivatives which strongly support our suggestion. Furthermore, the exact determination of the positions of the substituents in $\mathbf{1 2}$ and $\mathbf{1 7}$ supports our proposed mechanism.

The formation of the compounds having cyclopentadienone structures such $\mathbf{6 , 8 , 1 3}$ as well as 9, however, cannot be explained via this mechanism. As one can easily recognize from the position of the substituents in $\mathbf{1 3}$, for the construction of this skeleton requires a $\mathrm{C}-\mathrm{C}$ connection of methylene groups of two homophthalic acid units.

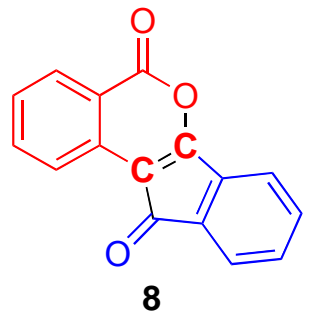

Before such a $\mathrm{C}-\mathrm{C}$ connection between the two methylene groups can take place, one of these groups should contain a good leaving group. We therefore assume, that firstly a chlorination on one of the methylene goups ${ }^{20}$ takes place under the reaction conditions, followed by attack of the enol form of the second methylene group. Decarboxylation and cyclization can then lead to the compounds $\mathbf{8}$ and $\mathbf{1 3}$.

\section{Experimental Section}

General. Melting points were determined on a Thomas-Hoover capillary melting point apparatus. IR spectra were recorded on a Perkin Elmer 980 spectrometer. NMR spectra were recorded on a Bruker-Avance instrument at $400 \mathrm{MHz}$ for ${ }^{1} \mathrm{H}$ and $100 \mathrm{MHz}$ for ${ }^{13} \mathrm{C} \mathrm{NMR}$. Apparent splitting is given in all cases. Mass spectra were recorded on an Agilent 5975C spectrometer operating at an ionization potential of $70 \mathrm{eV}$. Column chromatography was performed on silica gel (60-mesh, Merck). TLC was carried out on Merck $0.2 \mathrm{~mm}$ silica gel 60 $\mathrm{F}_{254}$ analytical aluminum plates.

Synthesis of $\mathbf{6 H}$-dibenzo[c, $\boldsymbol{h}$ ]chromen-6-one (1). In a $25 \mathrm{~mL}$ dropping funnel, benzene $(7 \mathrm{~mL})$, dimethyl formamide $(2,8 \mathrm{~mL})$ and thionyl chloride $(2.3 \mathrm{~mL})$ were consecutively added. The formed solution was allowed to form two separate layers. The lower layer was added to a suspension of the homophthalic acid $5(2.5 \mathrm{~g}, 13.9 \mathrm{mmol})$, sodium azide $(2.6 \mathrm{~g}, 44 \mathrm{mmol})$, tetrabutylammonium bromide $(0.6 \mathrm{~g}, 2.3 \mathrm{mmol})$, and pyridine $(3.2 \mathrm{~mL})$ in dichloromethane $(100$ $\mathrm{mL}$ ). The mixture was then stirred at room temperature overnight and washed with saturated aqueous sodium bicarbonate solution $(3 \times 50 \mathrm{~mL})$, with $1.0 \mathrm{M} \mathrm{HCl}$ solution $(3 \times 50)$ three times and finally with water $(2 \times 25 \mathrm{~mL})$. The organic phase was dried over magnesium sulfate and 
concentrated under reduced pressure. The residue was purified by column chromatography (silica gel, $\left.40 \mathrm{~g}, \mathrm{CH}_{2} \mathrm{Cl}_{2}\right)$ to give colorless crystals $\mathbf{1}\left(0.7 \mathrm{~g}, \mathrm{mp}, 182-183^{\circ} \mathrm{C}^{9}\right.$, Lit. mp. 179-180 ${ }^{\circ} \mathrm{C}^{11}$ ) in $41 \%$ yield. The product was recrystallized from ethyl acetate. The NMR spectra were in agreement with those reported in the literature., ${ }^{9,11}$ As the second fraction indeno[1,2c]isothiochromene-5,11-dione $\mathbf{6}$ was isolated.

Red crystals ( $73 \mathrm{mg}, 4 \%$ ) from methylene chloride, $\mathrm{mp} 235-236{ }^{\circ} \mathrm{C}$ (Found: $\mathrm{C}, 71.32 ; \mathrm{H}, 3.09$; $\mathrm{S}$, 12.34\% $\mathrm{C}_{16} \mathrm{H}_{8} \mathrm{O}_{2} \mathrm{~S}$ requires : C, 72.71; H, 3.05; $\mathrm{S}, 12.13 \% \mathrm{IR} v_{\max }(\mathrm{KBr}) / \mathrm{cm}^{-1} 2989,1699,1654$, 1275, 1262, 764, 750; ${ }^{1} \mathrm{H}-\mathrm{NMR}\left(400 \mathrm{MHz}, \mathrm{CDCl}_{3}\right) \delta 8.95$ (d, $\left.J=8.1 \mathrm{~Hz}, \mathrm{H}-1\right), 8.17$ (d, $J=8.0$ Hz, H-4), 7.72 (t, $J=7.5 \mathrm{~Hz}, \mathrm{H}-2), 7.50$ (d, $J=7.1 \mathrm{~Hz}, \mathrm{H}-10), 7.47$ (t, $J=7.7 \mathrm{~Hz}, \mathrm{H}-3), 7.40$ (t, $J=7.4, \mathrm{H}-8), 7.31$ (t, $J=7.4 \mathrm{~Hz}, \mathrm{H}-9), 7.17$ (d, $J=7.3 \mathrm{~Hz}, \mathrm{H}-7) .{ }^{13} \mathrm{C}-\mathrm{NMR}\left(100 \mathrm{MHz}, \mathrm{CDCl}_{3}\right)$ $\delta 191.3$ (C-11), 183.1 (C-5), 156.2 (C-6a), 140.6 (C-6b), 135.0 (C-2), 134.1 (C-8), 133.8 (C11b), 133.3 (C-9), 131.1 (C-10a), 128.6 (C-3), 127.0 (C-4), 126.5 (C-11a), 126.3 (C-1), 123.1 (C-10), 119.9 (C-4a), 119.7 (C-7). MS, m/z 264 (M $\left.{ }^{+}, 100 \%\right), 236\left(\mathrm{M}^{+}-\mathrm{CO}, 81 \%\right), 208\left(\mathrm{M}^{+}-\right.$ 2CO, 27\%), $176\left(\mathrm{M}^{+}-2 \mathrm{CO},-\mathrm{S}, 10 \%\right), 163(35 \%), 104(22 \%)$.

\section{Reaction of homophthalic acid with thionyl chloride and sodium azide in the absence of dimethyl formamide}

To a suspension of homophthalic acid (5.0 g, $27.8 \mathrm{mmol}), \mathrm{NaN}_{3}(7.2 \mathrm{~g}, 111 \mathrm{mmol})$, tetrabutylammonium bromide $(0.75 \mathrm{~g}, 2.3 \mathrm{mmol})$, and pyridine $(9 \mathrm{~mL})$ in dichloromethane $(100 \mathrm{~mL})$, thionyl chloride $(4.6 \mathrm{~mL}, 63.4 \mathrm{~mL})$ was added dropwise under a nitrogen atmosphere and the mixture was stirred at room temperature for $10 \mathrm{~h}$. The inorganic salts were separated by filtration. The filtrate was washed with $1.0 \mathrm{M} \mathrm{HCl}$ solution three times, followed by water extraction. The organic phase was dried $\left(\mathrm{MgSO}_{4}\right)$ and solvent removed under reduced pressure. The residue was purified by chromatography over silica gel (60 g) eluting with methylene chloride.

Sulfur (340 mg, $10.6 \mathrm{mmol})$ was isolated as the first fraction. The compound 6 (623 $\mathrm{mg}, 17 \%)$ was isolated as the second fraction. The third fraction was characterized as 8. Indeno[1,2c]isochromene-5,11-dione (8). Yellow solid (275 mg, 8\%), m.p. 257-258 ${ }^{\circ} \mathrm{C}$ (Lit. 258-259 $\left.{ }^{\circ} \mathrm{C}^{13 \mathrm{~b}}\right) 403 \mathrm{mg}, 8 \%$, yellow solid; ${ }^{1} \mathrm{H}-\mathrm{NMR}\left(\mathrm{CDCl}_{3}, \mathrm{TMS}\right) \delta 8.31(\mathrm{~d}, J=7.9 \mathrm{~Hz}, \mathrm{H}-1), 8.23(\mathrm{~d}, J$ $=8.0 \mathrm{~Hz}, \mathrm{H}-4), 7.74$ (t, $J=7.6 \mathrm{~Hz}, \mathrm{H}-2), 7.52$ (d, $J=7.1, \mathrm{H}-10), 7.48$ (d, $J=7.4 \mathrm{~Hz}, \mathrm{H}-3), 7.45-$ $7.39(\mathrm{~m}, 2 \mathrm{H}, \mathrm{H}-7$ and $\mathrm{H}-8), 7.34$ (dt, $J=6.8$ and $1.8 \mathrm{~Hz}, \mathrm{H}-9) .{ }^{13} \mathrm{C}-\mathrm{NMR}\left(400 \mathrm{MHz}, \mathrm{CDCl}_{3}\right)$ $\delta 189.9$ (C-11), 170.6 (C-5), 160.8 (C-6a), 136.4 (C-6b), 136.0 (C-2), 133.6 (C-8), 132.8 (C-10 or C-11b), 132.8 (C-10 or C-11b), 131.6 (C-8), 130.9 (C-4), 128.4 (C-3), 123.3 (C-1), 123.1 (C10), 119.9 (C-7), 119.0 (C-4a), 107.7 (C-11a). MS m/z ( $\left.\mathrm{C}_{16} \mathrm{H}_{8} \mathrm{O}_{3}\right) 248$ ( $\left.\mathrm{M}^{+}, 100 \%\right), 220\left(\mathrm{M}^{+}-\mathrm{CO}\right.$, 19), $163(30)$.

Dibenzo[c,h]indeno[2,1-f]chromene-5,11-dione (9) was isolated as the fourth fraction. Yellow solid, m.p. 212-213 ${ }^{\circ} \mathrm{C}$ (451 mg, 14\%); HRMS calcd for $\mathrm{C}_{24} \mathrm{H}_{12} \mathrm{O}_{3}\left(\mathrm{M}^{+}+\mathrm{H}\right)$ 349.0865; found 349.0871; IR $v_{\max } / \mathrm{cm}^{-1} 2955,2922$ 2852, 1727, 1706, 1286, 1259, 1103, 742; ${ }^{1} \mathrm{H}-\mathrm{NMR}$ (400 MHz, benzene- $\left.d_{6}\right) \delta 9.33(\mathrm{~d}, J=8.4 \mathrm{~Hz}, 1 \mathrm{H}, \mathrm{H}-10), 8.30(\mathrm{dd}, J=7.8$ and $1.3 \mathrm{~Hz}, 1 \mathrm{H}, \mathrm{H}-4), 8.25$ (d, $J=8.4 \mathrm{~Hz}, 1 \mathrm{H}, \mathrm{H}-7), 7.89$ (d, $J=7.6 \mathrm{~Hz}, 1 \mathrm{H}, \mathrm{H}-1), 7.59$ (dd, $J=7.0$ and $1.0 \mathrm{~Hz}, 1 \mathrm{H}, \mathrm{H}-12$ ), 
7.40 (d, $J=7.5 \mathrm{~Hz}, 1 \mathrm{H}, \mathrm{H}-15), 7.26$ (ddd, $J=8.4,6.9$ and $1.2 \mathrm{~Hz}, 1 \mathrm{H}, \mathrm{H}-9), 7.09$ (ddd, $J=8.4$, 6.9 and $1.2 \mathrm{~Hz}, 1 \mathrm{H}, \mathrm{H}-8), 7.05$ (ddd, $J=7.8,7.4$ and $1.5 \mathrm{~Hz}, 1 \mathrm{H}, \mathrm{H}-2), 6.98(\mathrm{~d}, J=7.8$ and 1.5 $\mathrm{Hz}, 1 \mathrm{H}, \mathrm{H}-3$ ), 6.87 (dd, $J=7.5$ and $1.3 \mathrm{~Hz}, 1 \mathrm{H}, \mathrm{H}-14), 6.80$ (d, $J=7.5$ and $0.9 \mathrm{~Hz}, 1 \mathrm{H}, \mathrm{H}-13$ ). ${ }^{13} \mathrm{C}-\mathrm{NMR}\left(100 \mathrm{MHz}, \mathrm{CDCl}_{3}\right) \delta 191.8158 .0,151.2,142.3,141.7,133.8,132.3,131.6,131.4$, $129.4,129.1,128.7,128.0,127.4,126.2$, 125.5, 124.3,123.0, 122.7, 122.4, 122.1.121.4, 121.0, 109.5. MS m/z $348\left(\mathrm{M}^{+}, 1 \%\right), 296$ (100), 268 (17), 240( 45), 195 (18), 120 (36).

2-(1-Oxo-1H-isochromen-3-yl)benzonitrile (10) was isolated as the fifth fraction. M.p. 201-202 ${ }^{\circ} \mathrm{C}$, (225 mg, 7\%); HRMS calcd for $\mathrm{C}_{13} \mathrm{H}_{13} \mathrm{NO}_{4}(\mathrm{M}+\mathrm{K})^{+} 286.0270$; found 286.0260; IR $v_{\max }(\mathrm{KBr}) / \mathrm{cm}^{-1} 2962,2921,2851,2225,1732,1645,1606,1458,1259,1232,1033,1008$, 794; ${ }^{1} \mathrm{H}-\mathrm{NMR}\left(400 \mathrm{MHz}, \mathrm{CDCl}_{3}\right) \delta 8.33$ (d, $\left.J=8.4 \mathrm{~Hz}, 1 \mathrm{H}, \mathrm{H}-8\right), 7.99$ (dd, $J=8.0 \mathrm{~Hz}, 1 \mathrm{H}, \mathrm{H}-$ 6'), $7.80(\mathrm{dd}, J=7.8$ and $1.1 \mathrm{~Hz}, 1 \mathrm{H}, \mathrm{H}-3$ '), 7.76 (ddd, $J=7.8,7.3$ and $1.3 \mathrm{~Hz}, 1 \mathrm{H}, \mathrm{H}-6), 7.71$ $(\mathrm{dd}, J=7.95$ and $1.37 \mathrm{~Hz}, 1 \mathrm{H}, \mathrm{H}-5$ '), $7.58(\mathrm{dd}, J=7.3$ and $1.5 \mathrm{~Hz}, 1 \mathrm{H}, \mathrm{H}-5), 7.57(\mathrm{dd}, J=8.4$ and $7.8 \mathrm{~Hz}, 1 \mathrm{H}, \mathrm{H}-7), 7.52$ (dd, $J=7.6$ and $1.2 \mathrm{~Hz}, 1 \mathrm{H}, \mathrm{H}-4), 7.32(\mathrm{~s}, 1 \mathrm{H}, \mathrm{H}-4) ;{ }^{13} \mathrm{C}-\mathrm{NMR}(100$ $\left.\mathrm{MHz}, \mathrm{CDCl}_{3}\right) \delta 160.0,148.2,134.9,133.6,133.5,132.8,131.4,128.09,128.06,127.7,127.1$, 125.1, 119.3, 116.4, 107.8, 105.5; MS (70 eV) 247 (M+100\%), 219 (39), 190 (51), 164 (11), 130 (13), 89 (32).

5-Bromo-2-(carboxymethyl)benzoic acid (11). Homophthalic acid 5 (5.0 g, $27 \mathrm{mmol}$ ) and potassium bromate $(6.58 \mathrm{~g}, 40 \mathrm{mmol})$ were mixed in water $(30 \mathrm{~mL})$ and the mixture was heated at $90{ }^{\circ} \mathrm{C}$. A mixture of sulfuric acid $(24 \mathrm{ml}, 95 \%)$ and water $(40 \mathrm{~mL})$ was added dropwise to the resulting mixture at $90{ }^{\circ} \mathrm{C}$ over a period of $30 \mathrm{~min}$. After completion of addition the mixture was stirred $2 \mathrm{~h}$ at the same temperature. Then the mixture was cooled to the room temperature and the product was filtered off and washed with water $(3 \times 50 \mathrm{~mL})$ to give $11(3.2 \mathrm{~g}, 44 \%)$. The product was recrystallized from EtOAc/hexane (4/1), m.p. 216-217, m.p. 215 ${ }^{16}$ ). ${ }^{1} \mathrm{H}-\mathrm{NMR}$ (400 MHz, DMSO-d $\left.d_{6}\right) \delta .99\left(\mathrm{~d}, J_{6,2}=2.4 \mathrm{~Hz}, 1 \mathrm{H}, \mathrm{H}-6\right), 7.71\left(\mathrm{dd}, J_{2,3}=8.0 \mathrm{~Hz}, J_{2,6}=2.4 \mathrm{~Hz}, 1 \mathrm{H}, \mathrm{H}-2\right.$ ), $7.31\left(\mathrm{~d}, J_{3,2}=8.0 \mathrm{~Hz}, 1 \mathrm{H}, \mathrm{H}-3\right.$ ), $3.92\left(\mathrm{~s}, 2 \mathrm{H},-\mathrm{CH}_{2}\right) ;{ }^{13} \mathrm{C}-\mathrm{NMR}\left(100 \mathrm{MHz}, \mathrm{DMSO}-d_{6}\right) \delta 172.0$, $166.9,135.9,134.5,134.4,132.7,132.6,119.7,39.2$.

3,8-Dibromo-6H-dibenzo[c,h]chromen-6-one (12). 5-Bromo-2-(carboxymethyl)-benzoic acid (11) (1.45 g, $5.6 \mathrm{mmol}), \mathrm{NaN}_{3}(1.45 \mathrm{~g}, 43 \mathrm{mmol})$, tetrabutylammonium bromide $(0.3 \mathrm{~g}, 1.15$ mmol) and pyridine $(1.8 \mathrm{~mL})$ were added to $100 \mathrm{~mL}$ of $\mathrm{CH}_{2} \mathrm{Cl}_{2}$. In a dropping funnel, $2.0 \mathrm{~mL}$ of dry benzene, $1.2 \mathrm{~mL}$ of $N, N$-dimethylformamide and $0.92 \mathrm{~mL} \mathrm{SOCl}_{2}$ were mixed and the solution was left to form two separate layers. After $10 \mathrm{~min}$, the bottom phase was added dropwise to the mixture prepared above. The resulting mixture was stirred for $18 \mathrm{~h}$. Inorganic non-reacted starting materials were removed by filtration. The filtrate was washed with $0.1 \mathrm{M}$ $\mathrm{HCl}(3 \times 50 \mathrm{~mL})$ followed by water $(3 \times 100 \mathrm{~mL})$ and dried over $\mathrm{MgSO}_{4}$. Removal of the solvent under reduced pressure gave the crude product, which was purified by chromatography on silica gel (40 g) eluting with $\mathrm{CH}_{2} \mathrm{Cl}_{2}$. As the first fraction the thioisocoumarin derivative 13, which could not be purified, was isolated, $24 \mathrm{mg}$ (orange solid), $2 \%$, purity about $85 \%$ according to the ${ }^{1} \mathrm{H}-\mathrm{NMR}$.

3,8-Dibromoindeno[1,2-c]thioisochromene-5,11-dione (13). Orange solid. ${ }^{1} \mathrm{H}-\mathrm{NMR}$ (400 $\left.\mathrm{MHz} \mathrm{CDCl}_{3}\right) \delta 8.80(\mathrm{~d}, J=8.7 \mathrm{~Hz}, \mathrm{H}-1), 8.30(\mathrm{~d}, J=2.0 \mathrm{~Hz}, \mathrm{H}-4), 7.8(\mathrm{dd}, J=8.7$ and $2.0 \mathrm{~Hz}$, 
H-2), 7.64 (d, $J=1.7 \mathrm{~Hz}, \mathrm{H}-10), 7.57$ (dd. $J=7.7$ and $1.7 \mathrm{~Hz}, \mathrm{H}-8), 7.06$ (d, $J=7.7 \mathrm{~Hz}, \mathrm{H}-7$ ). MS $m / z\left(\mathrm{C}_{16} \mathrm{H}_{6} \mathrm{Br}_{2} \mathrm{O}_{2} \mathrm{~S}\right) 420 / 422 / 424\left(\mathrm{M}^{+}, 32,65,33 \%\right), 394 / 396 / 398\left(\mathrm{M}^{+}-\mathrm{CO} 32 \%\right), 316 / 318$ $\left(\mathrm{M}^{+}-\mathrm{Br}\right.$ and $\left.-\mathrm{CO}, 10 \%\right), 211(100 \%), 167(58 \%), 109(51 \%)$.

The second fraction was identified as dibromobenzochromenone 12. $433 \mathrm{mg} \mathrm{(37 \% )}$ as a white solid, m.p. 312-323 ${ }^{\circ} \mathrm{C}$. (Found: C, 50.11; H, 2.00\% $\mathrm{C}_{17} \mathrm{H}_{8} \mathrm{Br}_{2} \mathrm{O}_{2}$ requires C, 50.53; H, 2.00\%); IR $v_{\max }(\mathrm{KBr}) / \mathrm{cm}^{-1} 3079,2919,1711,1482,1262,1230,1185,827 ;{ }^{1} \mathrm{H}-\mathrm{NMR}\left(400 \mathrm{MHz}, \mathrm{CDCl}_{3}\right)$ $\delta 8.73(\mathrm{~d}, J=1.9 \mathrm{~Hz}, \mathrm{H}-4), 8.60(\mathrm{~d}, J=2.1 \mathrm{~Hz}, \mathrm{H}-7), 8.05$ (d, $J=8.6 \mathrm{~Hz}, \mathrm{H}-10), 8.02$ (d, $J=8.9$ $\mathrm{Hz}, \mathrm{H}-11), 7.96$ (dd, $J=8.6$ and $2.1 \mathrm{~Hz}, \mathrm{H}-9), 7.74$ (2d, $J=8.4 \mathrm{~Hz}, \mathrm{H}-1$ and H-12) 7.68 (dd, $J$ $=8.7$ and $1.9 \mathrm{~Hz}, \mathrm{H}-2) .{ }^{13} \mathrm{C}-\mathrm{NMR}$ spectrum could not be taken due to the poor solubility of the compound. MS Spectrum: $70 \mathrm{eV}, \mathrm{m} / \mathrm{z} ; 402 / 404 / 406\left(\mathrm{M}^{+}, 52,100,49 \%\right), 295 / 297\left(\mathrm{M}^{+}-\mathrm{Br}\right.$, $17 \%), 267 / 269\left(\mathrm{M}^{+}-\mathrm{Br}\right.$, and -CO, 11\%), $216(9 \%), 187(41 \%)$.

3,8-Dimethoxyindeno[1,2-c]isochromene-5,11-dione (17). 2-(Carboxymethyl)-5-methoxybenzoic acid $(1.275 \mathrm{~g}, 6.07 \mathrm{mmol}) \mathrm{NaN}_{3}(1.574 \mathrm{~g}, 46.7 \mathrm{mmol})$, tetrabutylammonium bromide $(0.32 \mathrm{~g}, 1.23 \mathrm{mmol})$ and $2.0 \mathrm{~mL}$ pyridine, $1.2 \mathrm{~mL}$ of $N, N$-dimethylformamide and $0.92 \mathrm{~mL}$ $\mathrm{SOCl}_{2}$ were reacted as described above. After the normal work-up procedure, the residue was purified by chromatography on silica gel $(40 \mathrm{~g})$ eluting with $\mathrm{CH}_{2} \mathrm{Cl}_{2}$. 3,8-Dimethoxy- $6 \mathrm{H}$ dibenzo $[c, h]$ chromen-6-one (17) was isolated as white solid $(0.48 \mathrm{~g}, 45 \%)$, m.p. $244-245{ }^{\circ} \mathrm{C}$; (Found: C, 73.98; H, 4.71\%; $\mathrm{C}_{19} \mathrm{H}_{14} \mathrm{O}_{4}$ requires C, 74.50; H, 4.61\%); IR $v_{\max }(\mathrm{KBr}) / \mathrm{cm}^{-1} 3075$, 2945, 2840, 1712, 1609, 1498, 1223, 1061, 1020, 8228; ${ }^{1} \mathrm{H}-\mathrm{NMR}\left(400 \mathrm{MHz}, \mathrm{CDCl}_{3}\right) \delta 7.99(\mathrm{~d}, J$ $=8.9 \mathrm{~Hz}, \mathrm{H}-10), 7.74$ (d, $J=2.8 \mathrm{~Hz}, \mathrm{H}-7), 7.75$ (d, $J=8.7 \mathrm{~Hz}, \mathrm{H}-12), 7.69$ (d, $J=2.4 \mathrm{~Hz}, \mathrm{H}-1)$, $7.65 \mathrm{~d}, J=8.9 \mathrm{~Hz}, \mathrm{H}-4), 7.57$ (d, $J=8.7 \mathrm{~Hz}, \mathrm{H}-11), 7.34$ (dd, $J=8.9$ and $2.8 \mathrm{~Hz}, \mathrm{H}-9), / .12(\mathrm{dd}$, $J=8.9$ and $2.5 \mathrm{~Hz}, \mathrm{H}-3), 3.95(\mathrm{~s}, 3 \mathrm{H}), 3.92(\mathrm{~s}, 3 \mathrm{H}) .{ }^{13} \mathrm{C}-\mathrm{NMR}\left(100 \mathrm{MHz}, \mathrm{CDCl}_{3}\right) \delta 161.5(\mathrm{C}-6)$, 159.8 (C-8), 158.7 (C-2), 145.3 (C-4b), 129.3 (C-4), 129.1 (C-10a), 129.0 (C-4a), 125.0 (C-9), 124.5 (C-3), 124.2 (C-12a), 123.9 (C-10), 122.3 (C-6a), 120.3 (C-3), 116.5 (C-11), 113.7 (c$10 b), 100.1(\mathrm{C}-1), 55.84\left(\mathrm{OCH}_{3}\right), 55.78\left(\mathrm{OCH}_{3}\right)$. MS m/z $306\left(\mathrm{M}^{+}, 100 \%\right), 263$ (21\%), 220 (10), $192(9), 163(12)$,

(Z)-4-[(Dimethylamino)methylene]-7-methoxyisochroman-1,3-dione (18). 2-(Carboxymethyl)-5-methoxybenzoic acid (16) $(130 \mathrm{mg}, 0.62 \mathrm{mmol})$ tetrabutylammonium bromide (32 $\mathrm{mg}$ g, $0.12 \mathrm{mmol})$ and pyridine $(0.3 \mathrm{~mL})$, benzene $(0.4 \mathrm{~mL}) N, N$-dimethylformamide $0.15 \mathrm{~mL})$ and $\mathrm{SOCl}_{2}(0.12 \mathrm{~mL})$ in $40 \mathrm{~mL}$ of $\mathrm{CH}_{2} \mathrm{Cl}_{2}$ were reacted as described above. The resulting mixture was stirred overnight. Inorganic non-reacted starting materials were removed. The filtrate was washed with $0.3 \mathrm{M} \mathrm{HCl}$ solution three times. The organic phase was dried over $\mathrm{MgSO}_{4}$. Removal of the solvent gave the crude product, which was purified by chromatography on silica gel $(10 \mathrm{~g})$ eluting with ethyl acetate to give a yellow solid $123 \mathrm{mg}, 82 \%) .{ }^{1} \mathrm{H}-\mathrm{NMR}$ (400 MHz, $\left.\mathrm{CDCl}_{3}\right) \delta 7.78$ (bs, H-5), 7.49 (t, $J=1.6 \mathrm{~Hz}, \mathrm{H}-8$ ), 7.09 (dd, $J=7.2$ and $2.4 \mathrm{~Hz}, \mathrm{H}-6$ ), 3.87 (s, $\left.3 \mathrm{H},-\mathrm{OCH}_{3}\right), 3.24\left(\mathrm{bs}, 6 \mathrm{H},-\mathrm{NCH}_{3}\right) .{ }^{13} \mathrm{C}-\mathrm{NMR}\left(100 \mathrm{MHz}, \mathrm{CDCl}_{3}\right) \delta 163.2,156.6,156.2,132.9$, 124.2, 120.4, 117.5, 111.4, 88.2, 55.6, 47.5, 45.0 MS m/z, $\left(\mathrm{C}_{13} \mathrm{H}_{13} \mathrm{NO}_{4}\right) 247\left(\mathrm{M}^{+}, 100 \%\right), 204.0$ (85), 188.1 (18), $160.1(19), 132.1(61)$. 
Methyl 7-methoxy-1-oxo-1H-isochromene-4-carboxylate (19). (Z)-4-((dimethylamino)methylene)-7-methoxyisochroman-1,3-dione (18) (65 mg, $0.26 \mathrm{mmol}$ ) was dissolved in methanol $(20 \mathrm{~mL})$. Dry $\mathrm{HCl}$ gas produced from sulfuric acid and sodium chloride was passed slowly through this solution. After the saturation was completed, it was refluxed for $2 \mathrm{~h}$. The solvent was removed under reduced pressure, water was added to the residue which was then extracted with chloroform $(3 \times 10 \mathrm{~mL})$. The combined extracts were dried $(\mathrm{MgSO} 4)$ and the solvent was removed at reduced pressure. The residue was purified by chromatography on silica gel eluting with ethyl acetate/hexane (3:2) to yield $17.5 \mathrm{mg} \mathrm{29 \%}$ (isolated yield) of methyl 7-methoxy-1oxo-1H-isochromene-4-carboxylate (19), as a white solid (m.p. 121-123 ${ }^{\circ} \mathrm{C}, 124-125{ }^{\circ} \mathrm{C}^{18}$ ); ${ }^{1} \mathrm{H}$ NMR (400 MHz, CDCl3,) $\delta 8.57$ (d, $J=9.1 \mathrm{~Hz}, \mathrm{H}-5), 8.10$ (s, H-3), 7.71 (d, $J=2.9 \mathrm{~Hz}, \mathrm{H}-8$ ), 7.37 (dd, $J=9.1$ and $2.9 \mathrm{~Hz}, \mathrm{H}-6), 3.90\left(\mathrm{~s}, 3 \mathrm{H},-\mathrm{OCH}_{3}\right), 3.89$ (s, 3H, $\left.-\mathrm{OCH}_{3}\right) .{ }^{13} \mathrm{C}-\mathrm{NMR}(100$ $\left.\mathrm{MHz}, \mathrm{CDCl}_{3}\right) \delta 164.7,161.0,159.9,150.5,127.3,127.0,124.5,121.91$ (C- ), 110.7), 109.9), 55.7, 52.1. $\mathrm{MS} \mathrm{m} / z,\left(\mathrm{C}_{12} \mathrm{H}_{10} \mathrm{O}_{5}\right)$ 234.1/235.1 $\left(\mathrm{M}^{+}, 8 / 1\right), 203.0\left(\mathrm{M}^{+}-\mathrm{OCH}_{3}\right), 202.0(-\mathrm{H}), 174.1$ ($\mathrm{CO}), 163.1$.

\section{Acknowledgements}

The authors are indebted to TUBITAK (Scientific and Technological Research Council of Turkey, Grant number 108-M168), Department of Chemistry at Middle East Technical University, and TUBA (Turkish Academy of Sciences) for their financial support of this work.

\section{References and Notes}

1. (a) Maskey, R. P.; Pusecker, K.; Speitling, M.; Monecke, P.; Helmke, E.; Laatsch, H. Z. Naturforsch., B Chem. Sci. 2002, 57, 823. (b) Fischer, C.; Lipata, F.; Rohr, J. J. Am. Chem. Soc. 2003, 125, 7818. (c) Cragg, G. M.; Newman, D. J.; Snader, K. M. J. Nat. Prod. Rep. 1997, 60, 52.

2. Ishii, H.; Ishikawa, T.; Haginiwa, J. Yakugaku Zasshi 1977, 97, 890, Chem. Abstr. 1977, 87, $197250 \mathrm{~g}$.

3. Ishii, H.; Ishikawa, T.; Murota, M.; Aoki, Y.; Harayama, T. J. Chem. Soc., Perkin Trans. 1 1993, 1019.

4. (a) Misra, R.; Tritch III, H. R.; Pandey, R. C. J. Antibiot. 1985, 38, 1280. (b) Nakano, H.; Matsuda, Y.; Ito, K.; Ohkubo, S.; Morimoto, M.; Tomita, F. J. Antibiot. 1981, 34, 266. (b) Balitz, D. M.; O’Herron, F. A.; Bush, J.; Vyas, D. M.; Nettleton, D. E.; Grulich, R. E.; Bradner, W. T.; Doyle, T. W. J. Antibiot. 1981, 34, 1544. (c) Hatano, K.; Hagashide, E.; Kameda, Y.; Horii, S.; Mizuno, K. Agric. Biol. Chem. 1980, 44, 1157.

5. James, C. A.; Snieckus, V. J. Org. Chem. 2009, 74, 4080.

6. Konno, F.; Ishikawa, T.; Kawahata, M.; Yamaguchi, K. J. Org. Chem. 2006, 71, 9818. 
7. Takemura, I.; Imura, K.; Matsumoto, T.; Suzuki, K. Org. Lett. 2004, 6, 2503.

8. Madan, S.; Cheng, C-H. J. Org. Chem. 2006, 71, 8312.

9. Ozcan, S.; Balci, M. Tetrahedron 2008, 64, 5531.

10. Arrieta, A.; Aizpurua, J. M.; Palomo, C. Tetrahedron Lett. 1984, 25, 3365.

11. Ozcan, S.; Şahin, E.; Balci, M. Tetrahedron Lett. 2007, 48, 2151.

12. Rayabarapu, D. K.; Shukla, P.; Cheng, C.-H. Org. Lett. 2003, 5, 4903.

13. (a) Morrell, A.; Placzek, M. S.; Steffen, J. D.; Antony, S.; Agama, K.; Pommier, Y.; Cushman, M. J. Med. Chem. 2007, 50, 2040. (b) Morrell, A.; Antony, S.; Kohlhagen, G.; Pommier, Y.; Cushman, M. Bioorg. Med. Chem. Lett. 2006, 16, 1846. (c) Wawzonek, S.; Hansen, G. R. J. Org. Chem. 1975, 40, 2974.

14. We have recently found that sodium azide can reduce 1,4-benzoquinones to the corresponding hydroquinones in high yields. Algi, F.; Balci, M. Synth. Commun. 2006, 36, 2293.

15. For bromination of deactivated aromatics using potassium bromate see: Harrison, J. J.; Pellegrini, J. P.; Selwitz, C. M. J. Org. Chem. 1981, 46, 2169.

16. Billamboz, M.; Fabrice, B.; Barreca, M. L.; De Luca, L.; Mouscadet, J-F.; Calmels, C.; Andreola, M-L.; Witvrouw, M.; Christ, F.; Debyser, Z.; Cotelle, P. J. Med. Chem. 2008, 51, 7717.

17. (a) Desai, H. K.; Usgaonkar, R. N. J. Indian Chem. Soc. 1963, 40, 239. (b) 17; Hill, R. A.; Rudra, S.; Peng, B.; Roane, D. S.; Bounds, J. K.; Zhang, Y.; Adloo, A.; Lu, T. Bioorg. Med. Chem. 2003, 11, 2099.

18. Belgaonkar, V. H.; Usgaonkar, R. N. Tetrahedron Lett. 1975, 16, 3849; Ungnade, H. E.; Nightingale, D. V.; French, H. E. J. Org. Chem. 1945, 10, 533.

19. Sunderland, P. T.; Thompson, A. S.; Threadgill, M. D. J. Org. Chem. 2007, 72, 7409.

20. (a) For chlorination of carbonyl groups see: Solladie-Cavallo, A.; Bouerat, L. Tetrahedron Asymm. 2000, 11, 935. (b) Ambrosini, M.; Baricordi, N.; Benetti, S.; De Risi, C.; Pollini, G. P.; Zanirato, V. Tetrahedron: Asymmetry 2009, 20, 2145. 